\title{
Effect of Moringa oleifera (Lam.) pods as feed additive on egg antioxidants, chemical composition and performance of commercial layers
}

\author{
S. Ahmad ${ }^{1 \#}$, A. Khalique ${ }^{1}$, T. N. Pasha', S. Mehmood², K. Hussain ${ }^{3}$, S. Ahmad ${ }^{2}$, M. S. \\ Shaheen ${ }^{2}$, M. Naeem ${ }^{4} \&$ M. Shafiq ${ }^{2}$ \\ ${ }^{1}$ Department of Animal Nutrition, Faculty of Animal Production and Technology, University of Veterinary and Animal \\ Sciences, Lahore, Pakistan, 54000 \\ ${ }^{2}$ Department of Poultry Production, Faculty of Animal Production and Technology, University of Veterinary and Animal \\ Sciences, Lahore, Pakistan, 54000 \\ ${ }^{3}$ Punjab University College of Pharmacy, University of Punjab, Lahore, Pakistan \\ ${ }^{4}$ Poultry Research Institute, Livestock and Dairy Development Department, Government of Punjab, Pakistan
}

(Received 31 July 2017; Accepted 2 September 2017; First published online 6 October 2017)

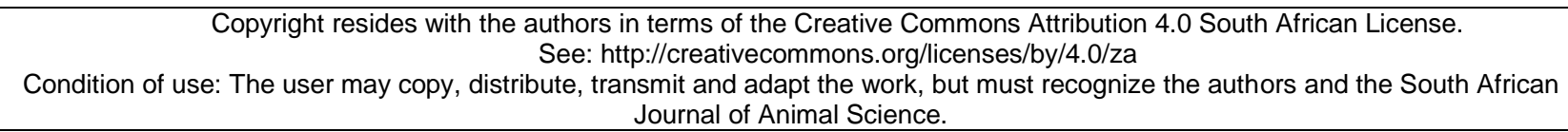
Journal of Animal Science.

\begin{abstract}
The present study was designed to investigate the influence of Moringa oleifera (Lam.) pod meal (MPM) on production, immunity, and functional food index of chicken eggs. Two hundred HyLine W36 layer birds aged 50 weeks, $1469 \pm 46.63 \mathrm{~g}$, were assigned to four treatments in a completely randomized design, with five replicates and ten birds each. Diets $A, B, C$, and D were formulated with the same caloric and protein levels, but with differing MPM dose levels of $0,5,10$, and $15 \mathrm{~g}$ MPM/kg finisher diet, respectively. Data for production performance, quality, and chemical composition of eggs were analysed by one-way ANOVA, and means were compared with Duncan's multiple range test. As a result of this study, feed conversion ratio (FCR) and egg mass (EM) were significantly decreased and recorded lowest in Group B, which was offered $5 \mathrm{~g} / \mathrm{kg}$ above the basal diet. Bioactives such as $\beta$-carotene, quercetin, and selenium levels were increased $(540,121, \& 72.21 \mu \mathrm{g} / 100 \mathrm{~g}$ of yolk, respectively), whereas cholesterol levels in egg yolk and serum were decreased significantly, that is, $201.87 \mathrm{mg} / 100 \mathrm{~g}$ and $8.47 \mathrm{mg} / \mathrm{dl}$, respectively. Serum biochemical indicators, including serum glutamic-pyruvic transaminase (SGPT), glucose, creatinine and cholesterol levels, were lowered significantly. Proximate analysis of egg yolk showed that moisture and ether extract were decreased, whereas crude protein $(\mathrm{CP})$, ash and minerals, sodium $(\mathrm{Na})$, potassium $(\mathrm{K})$, calcium $(\mathrm{Ca})$, magnesium $(\mathrm{Mg})$, and phosphorus $(\mathrm{P})$ contents were increased. The outcomes of this study showed that MPM supplementation affects EM, serum biochemistry and bioactive compounds of the egg yolk positively.
\end{abstract}

Keywords: Antibody titers, $\beta$-carotene, cholesterol, egg quality, quercetin, selenium

\#Corresponding author: 2011-phd-2010@uvas.edu.pk

\section{Introduction}

Conventional synthetic feed additives such as antibiotic growth promoters, antioxidants, anti-parasitic agents, and anti-fungal agents have been used in poultry feed for decades. However, they created multiple complications, such as traceability in animal products and resistance to antibiotics in the consumer, which became public health issues (Wallace et al., 2010; Ao et al., 2011; Kirkpinar et al., 2011;Embuscado, 2015;). On these grounds, the use of all kinds of antibiotic growth promoters was banned in animal feed in Europe (Nkukwana et al., 2014a). Revolutions in animal feed production gave rise to the idea of phytogenic feed additives (Grashorn, 2010). Plants and their metabolites, known as bioactive compounds, play a key role because of their feed additive attributes. These bioactive compounds, such as carotenoids, flavonoids, and essential oils, help to maintain animal health and productivity, and to produce safe and healthy chicken eggs (Windisch et al., 2008; Wallace et al., 2010; Ao et al., 2011; Embuscado, 2015). The primary mode of action of these active ingredients is inhibition of pathogenic microbes and endotoxins in the gut and enhanced pancreatic activity, resulting in better nutrient metabolism and utilization (Windisch et al., 2008; Grashorn, 2010).

To serve these objectives, several herbs, spices, and plant foliage (such as oregano, cinnamon, Capisicum oleoresin) were investigated for their feed additive attributes (Wallace et al., 2010; Ao et al., 2011; 
Kirkpinar et al., 2011; Moreki et al., 2014; Embuscado, 2015). Among the plants, Moringa oleifera (Lam.) is one of the best choices as it meets all the necessary parameters of a phytogenic feed additive (Rajasekaran et al., 2008). Moringa oleifera is widely distributed in the tropical and subtropical areas of the world, including Pakistan (Mughal et al., 1999; Anwar \& Bhanger, 2003). Based on potential nutrient and bioactive compounds, $M$. oleifera is a versatile tree, and is given considerable importance in poultry feed and human consumption (Manzoor et al., 2007; Fadiyimu et al., 2010; Ayasan, 2015). Its pods are rich in bioactive compounds, especially carotenoids ( $\beta$-carotene), flavonoids (quercetin), polyphenols, vitamins, and nutrients (Gopalakrishnanb et al., 2016). MPM could be a candidate phytogenic feed additive based on its bioactive compounds, which might add value to eggs and have positive impacts on animal health and performance (Yang et al., 2006; Portugaliza \& Fernandez, 2011; Zanu et al., 2012; Ola-Fadunsin \& Ademola, 2013). $\beta$ carotene and quercetin in Moringa pods range from 2.7 to $3.10 \mathrm{mg} / 100 \mathrm{~g}$ and 80 to $150 \mathrm{mg} / 100 \mathrm{~g}$ of dried pods, respectively (Amaglo, 2010; Saini et al., 2014a; Saini et al., 2014b). When added to the feed, these bioactives, along with phytochemicals, enrich eggs and have positive effects on the health and wellbeing of birds. Because of its higher protein concentration (22-25\%) and high profile of essential amino acids, Moringa pods can be used as a protein source in animal feed (Makkar \& Becker, 1996; Makkar \& Becker, 1997; Agbede, 2003; Aye \& Adegun, 2013).

Few studies are available on the use of Moringa pods as a phytogenic feed additive, and on its impact on bioactive compound enrichment in animal products. This study was planned in view of the challenges to animal feed producers regarding animal health, productivity, consumer health, traceability issues in animal products, and environment safety. Its objective was to investigate the effects of essential nutrients and antioxidant-enriched Moringa pods on production performance, immunity, and bioactive compounds of chicken eggs with various levels of supplementation.

\section{Materials and Methods}

Moringa oleifera pods were collected and stored in polythene bags after shade drying and grinding for further analysis and addition to feed (Banjo, 2012). The pod meal was analysed for chemical composition (Table 1) in the Department of Animal Nutrition laboratory, University of Veterinary and Animal Sciences (UVAS) and Pharmacy Department, University of Punjab, according to standard procedures (Mehta et al., 2003; AOAC, 2005). Selenium and bioactive compounds ( $\beta$-carotene and quercetin) were analysed with an atomic absorption spectrophotometer and high-performance liquid chromatography (HPLC), respectively, in Quality Operations Laboratory (QOL), UVAS (AOAC, 2005; Farida et al., 2008; Saini et al., 2014a).

Table 1 Chemical composition of Moringa oleifera pod meal

\begin{tabular}{lc}
\hline Chemical composition & Values \\
\hline Nutrients $\left(g / 100 g M^{*}\right)$ & 8.05 \\
Moisture & 18.98 \\
Crude protein & 2.34 \\
Ether extract & 7.88 \\
Ash & \\
Minerals (mg/100 g MPM) & 805 \\
Sodium & 2815 \\
Potassium & 291 \\
Calcium & 251 \\
Magnesium & 9456 \\
Phosphorus & 25.71 \\
Selenium & \\
Bioactive compounds (mg/100 g MPM) & 114 \\
Quercetin & 2.76 \\
B-Carotene &
\end{tabular}

*MPM: Moringa oleifera pod meal 
Two hundred (50 weeks old) commercial layer birds, with a production percentage of 65-66, were assigned to four treatments and five replicates with ten birds each in a completely randomized design. Four levels $(0,5,10$, and $15 \mathrm{~g} \mathrm{MPM} / \mathrm{kg}$ finished diet) of MPM were added to the four isocaloric and isonitrogenous diets: Diets A (ML 0\%), B (MLM 0.5\%), C (MLM 1.0\%), and D (MLM 1.5\%), with $160 \mathrm{~g} / \mathrm{kg}$ crude protein and $2725 \mathrm{kcal} / \mathrm{kg}$ metabolizable energy (Table 2).

Table 2 Ingredients and chemical composition of layer experimental diets

\begin{tabular}{|c|c|c|c|c|}
\hline Ingredients & A & B & C & D \\
\hline \multicolumn{5}{|l|}{ Stay here please } \\
\hline Maize & 50.00 & 50.00 & 50.00 & 50.00 \\
\hline Soybean meal $45 \%$ & 23.75 & 23.75 & 23.75 & 23.75 \\
\hline Rice polish (fat $>15 \%$ ) & 10.77 & 10.77 & 10.77 & 10.77 \\
\hline Limestone & 10.03 & 10.03 & 10.03 & 10.03 \\
\hline DCP & 2.24 & 2.24 & 2.24 & 2.24 \\
\hline Soy oil & 2.00 & 2.00 & 2.00 & 2.00 \\
\hline L-Threonine & 0.08 & 0.08 & 0.08 & 0.08 \\
\hline L-Lysine sulphate $55 \%$ & 0.27 & 0.27 & 0.27 & 0.27 \\
\hline Salt & 0.25 & 0.25 & 0.25 & 0.25 \\
\hline DL-Methionine & 0.23 & 0.23 & 0.23 & 0.23 \\
\hline Sodium bicarbonate & 0.18 & 0.18 & 0.18 & 0.18 \\
\hline Supplement & 0.20 & 0.20 & 0.20 & 0.20 \\
\hline Total & 100 & 100 & 100 & 100 \\
\hline Moringa pod (\%) & 0.00 & 0.50 & 1.00 & 1.50 \\
\hline \multicolumn{5}{|l|}{ Chemical composition } \\
\hline Dry matter & 90.26 & 90.26 & 90.26 & 90.26 \\
\hline Crude protein & 16.00 & 16.00 & 16.00 & 16.00 \\
\hline Metabolizable energy (kcal) & 2725 & 2725 & 2725 & 2725 \\
\hline Fat & 5.86 & 5.86 & 5.86 & 5.86 \\
\hline $\mathrm{CF}$ & 3.85 & 3.85 & 3.85 & 3.85 \\
\hline Ash & 11.74 & 11.74 & 11.74 & 11.74 \\
\hline Sodium & 0.19 & 0.19 & 0.19 & 0.19 \\
\hline Total phosphorus & 0.81 & 0.81 & 0.81 & 0.81 \\
\hline Calcium & 4.50 & 4.50 & 4.50 & 4.50 \\
\hline $\mathrm{Se}(\mathrm{mg} / \mathrm{kg})$ & 0.13 & 0.31 & 0.48 & 0.69 \\
\hline$\beta$-Carotene (mg/kg) & 0.31 & 0.58 & 0.74 & 0.83 \\
\hline $\begin{array}{l}\text { Quercetin }(\mathrm{mg} / \mathrm{kg}) \\
\text { Stay here please }\end{array}$ & 0.48 & 7.98 & 15.58 & 22.85 \\
\hline
\end{tabular}

Cholesterol estimation in the egg yolk samples was performed by the standard method using a UVvisible spectrophotometer (AOAC, 2005). Equal quantities of acetone and egg yolk were taken and shaken vigorously for two minutes. After centrifugation, the supernatant was removed. This procedure was repeated three times and the pooled supernatant was evaporated to remove acetone, and kept for cholesterol analysis. Before quantification of cholesterol, it was de-esterified. The supernatant was dissolved in a few $\mathrm{ml}$ isopropanol and vortexed. In another tube, $1 \mathrm{ml}$ sample was separated and $5 \mathrm{ml}$ isopropanol was added and again vortexed. Reagents were added in properly labelled cuvettes almost simultaneously. The samples were allowed to rest for 10 minutes and the absorbance read at 500nm.

Data were analysed through one-way ANOVA (Steel et al., 1997) using PROC GLM in SAS software (SAS Inc. 9.4). Significant means were separated through Duncan's multiple range test (Duncan, 1955). The following mathematical model was used: 


$$
Y_{i j}=\mu+T_{i}+\varepsilon_{i j}
$$

Where: $Y_{i j}=$ observation of dependent variable recorded on $i^{\text {th }}$ treatment

$$
\begin{aligned}
& \mu=\text { population mean } \\
& T_{i}=\text { effect of } i^{\text {th }} \text { level }(1,2,3,4) \\
& \varepsilon_{i j}=\text { residual effect of } j^{\text {th }} \text { observation on } i^{\text {th }} \text { treatment NID } \sim 0, \sigma^{2}
\end{aligned}
$$

A daily feed allowance of $100 \mathrm{~g}$ per bird was offered. Feed offered, feed refused, feed intake, and mortality were recorded daily and tabulated cumulatively for FCR every week. Daily egg production was recorded from each experimental unit separately to calculate various parameters, including EM, egg weight, feed per dozen eggs, and feed per kg eggs. Egg shape index, surface area, volume, shell thickness, yolk index, and Haugh unit score were measured at the start of the experiment and then every two weeks throughout the experimental period. Three eggs were picked at random from each unit and subjected to egg geometry measurement.

Bird handling and collection of samples were performed according to the procedure approved by Advance Studies and Research Board (ASRB), UVAS. Blood samples were taken with sterile syringes containing anticoagulant from the wing web on days 28 and 42 of the experiment and stored. Blood samples were centrifuged and the serum was separated and stored for analysis of parameters, including glucose, serum glutamic-pyruvic transaminase (SGPT), alanine transaminase (ALT), creatinine, and cholesterol, with protocols for every parameter using a commercial kit from Merck Microlab-300, in WTO Laboratory, University of Veterinary and Animal Sciences, Lahore Pakistan. The serum samples were analysed for antibody titers against Newcastle Disease by haemagglutination ( $\mathrm{HA})$ and haemagglutination inhibition (HI) techniques.

Egg yolk and feed samples were analysed to estimate moisture, crude protein, crude fibre, ether extract, and ash (AOAC, 2005). Ash samples were used for mineral analysis. The wet digestion procedure was used for selenium analysis (AOAC, 2005).

HPLC techniques were used to estimate carotenoids ( $\beta$-carotene) and flavonoids (quercetin) in the yolk samples (Tokusoglu et al., 2003; Saini et al., 2014b). Yolk samples were analysed for cholesterol level on a UV-visible spectrophotometric with the method described by AOAC (2005).

Quantification of carotenoids was done with the HPLC technique, and yolk samples were prepared as described by Saini et al. (2014a). In an HPLC tube $1 \mathrm{~g}$ yolk sample was weighed with $8 \mathrm{ml}$ methanol and 2 $\mathrm{ml} 1 \mathrm{~N} \mathrm{HCL}$. The yolk sample was vortexed for five minutes, and this process was repeated three times. The sample was centrifuged at $4000 \mathrm{rpm}$ for 15 minutes. The supernatant was removed and dried in a water bath. When the sample was dried, $1 \mathrm{ml}$ mobile phase was added with acetonitrile, dichloromethane and methanol in the ratio of 70:20:10 v/v/v. The sample was vortexed and filtered with Whatman filter paper and passed to the HPLC to quantify $\beta$-carotene. For this purpose, a C18 reverse phase column was used with inner dimensions of $250 \mathrm{~mm} \times 4.6 \mathrm{~mm}$, and a flow rate of $1 \mathrm{ml} \mathrm{min-1}-1$. A standard solution was prepared with 0.01 to $0.08 \mathrm{mg} / \mathrm{L}$ serial dilutions.

Egg yolk samples were analysed for quercetin levels using the HPLC technique with slight modifications to the standard method (Tokusoglu et al., 2003). For sample preparation, a measured $1 \mathrm{~g}$ weight of egg yolk was taken in HPLC tubes and acidified methanol was added. After lowering the temperature, the sample was centrifuged at $1500 \mathrm{~g}$ and $5000 \mathrm{rpm}$ for 15 minutes and repeated three times. The supernatant was filtered and shifted to HPLC vials for quercetin analysis. The sample volume injected was $20 \mu \mathrm{l}$ and the column used was reverse phase (C18) with dimensions $(250 \times 4.6 \mathrm{~mm} ; 5 \mu \mathrm{m}$ particle size). Two solvents, namely $3 \%$ trifluoro acetic acid and 80:20 v/v acetonitrile and methanol, were used as mobile phase in equal proportions and with a flow rate of $1.0 \mathrm{~mL} \mathrm{~min}-{ }^{1}$ at $30{ }^{\circ} \mathrm{C}$.

\section{Results and Discussion}

The results of the present study showed that supplementation of MPM to the layer diet affected EM and FCR per kg EM significantly $(P \leq 0.05)$. The results showed significant effect of MPM supplementation on EM and FCR per kg EM (Table 3). The best EM and FCR values were observed in Group B, which was supplemented with $5 \mathrm{~g} \mathrm{MPM} / \mathrm{kg}$ feed $(P \leq 0.05)$ (Table 3). All other parameters, including feed intake, egg weight, production percentage and FCR per dozen eggs, remained the same with the supplementation of MPM (Table 3). Improved EM and FCR may be attributed to the essential nutrients added by supplementation, especially amino acids (lysine, methionine) and vitamins, along with extra protein ( $0 \mathrm{~g}$, $0.10,0.19, \& 0.28 \mathrm{~g})$ per bird daily, in addition to total daily protein intake $(16 \mathrm{~g})$. Extra protein resulted in an increase in essential amino acids, especially methionine and lysine, which might affect EM positively (Rezaei et al., 2004). Higher fibre and anti-nutritional compounds resulted in bulkiness and decreased digestibility, 
which affected some parameters of production and egg quality negatively. Because the digestive system of poultry lacks fibre degrading enzymes, a quadratic response was observed with the higher dose level of MPM, which resulted in slightly poorer FCR and decreased EM compared with Diet $B$ with a $0.5 \%$ dose rate of MPM (Abou-Elezz et al., 2011; El-Sheikh et al., 2015). The lowest FCR recorded was 1.67 in Diet B, with the supplementation of $5 \mathrm{~g} \mathrm{MPM} / \mathrm{kg}$. Because feed intake was not significantly affected, there was no change in egg weight and production during the experimental period. Feed intake, egg weight, and egg production have positive correlations. Quercetin, a flavonoid that affects EM positively, improves FCR per kg EM (Mohammed et al., 2012; Liu et al., 2014). Similar results have been reported in other studies that showed the positive effect of Moringa on EM (Olugbemi, 2010). Contrary to these results, Paguia et al. (2014) used low levels ( $0 \%$ to $0.5 \%$ ) of Moringa leaf meal and reported that feed consumption, FCR and egg production remained unchanged.

Table 3 Mean $( \pm$ SE) production performance and egg characteristics of commercial layers fed on various levels of Moringa oleifera pod meal for 6 weeks (55-61 weeks old)

\begin{tabular}{lcccc}
\hline Parameter & A & B & C & D \\
\hline FI & $41.73 \pm 0.05$ & $41.78 \pm 0.04$ & $41.76 \pm 0.04$ & $41.70 \pm 0.05$ \\
EM & $23.78^{\mathrm{b}} \pm 0.41$ & $25.00^{\mathrm{a}} \pm 0.27$ & $24.69^{\mathrm{ab}} \pm 0.23$ & $24.26^{\mathrm{ab}} \pm 0.38$ \\
Egg weight & $62.42 \pm 0.83$ & $63.69 \pm 0.81$ & $63.52 \pm 0.42$ & $62.92 \pm 0.69$ \\
Production \% & $63.50 \pm 0.72$ & $65.41 \pm 0.75$ & $64.79 \pm 0.74$ & $64.28 \pm 0.48$ \\
FCRdz & $1.32 \pm 0.01$ & $1.28 \pm 0.01$ & $1.29 \pm 0.01$ & $1.30 \pm 0.01$ \\
FCRem & $1.76^{\mathrm{a}} \pm 0.03$ & $1.67^{\mathrm{b}} \pm 0.02$ & $1.69^{\mathrm{ab}} \pm 0.02$ & $1.72^{\mathrm{ab}} \pm 0.03$ \\
Egg characteristics & & & & \\
Shape index & $78.72 \pm 0.40$ & $78.35 \pm 0.42$ & $79.86 \pm 0.31$ & $78.75 \pm 0.73$ \\
Surface area & $72.60 \pm 1.24$ & $74.40 \pm 1.14$ & $75.45 \pm 1.00$ & $75.40 \pm 2.06$ \\
Volume & $52.42 \pm 1.34$ & $54.35 \pm 1.24$ & $55.49 \pm 1.10$ & $55.59 \pm 2.25$ \\
Yolk index & $35.59 \pm 0.84$ & $35.66 \pm 0.54$ & $35.09 \pm 0.32$ & $35.30 \pm 0.46$ \\
HU score & $86.77^{\mathrm{a}} \pm 0.58$ & $85.01^{\mathrm{b}} \pm 0.65$ & $86.09^{\mathrm{ab}} \pm 0.52$ & $87.31^{\mathrm{a}} \pm 0.43$ \\
ST value & $0.36^{\mathrm{a}} \pm 0.01$ & $0.37^{\mathrm{a}} \pm 0.01$ & $0.36^{\mathrm{a}} \pm 0.01$ & $0.33^{\mathrm{b}} \pm 0.01$ \\
& & & & \\
\hline Supersci & & &
\end{tabular}

Superscripts on different means within row show significant difference $(P \leq 0.05)$

Fl: feed Intake $(\mathrm{kg})$; EM: egg mass $(\mathrm{kg})$; egg weight $(\mathrm{g})$; FCRdz: feed conversion ratio/dozen eggs; FCRem: feed conversion ratio /kg EM; surface area $\left(\mathrm{cm}^{2}\right)$; volume $\left(\mathrm{cm}^{3}\right)$; HU: Haugh unit; ST: shell thickness $(\mathrm{mm}) ; \mathrm{A}, \mathrm{B}, \mathrm{C}$, and D: MPM dose levels of $0,5,10$, and $15 \mathrm{~g}$ respectively

MPM supplementation had a significant $(P \leq 0.05)$ effect on Haugh unit and egg shell thickness. Significant decreases in these parameters were observed with the increasing dose rate (Table 3). Egg shape index, surface area, volume, and egg yolk index remained unchanged during the experimental period. Highest values of Haugh unit and shell thickness were observed in the control group, which had no supplementation of MPM (Table 3). Quercetin in smaller quantities potentiates phytoestrogens, but in higher quantities may act as antagonists and block receptors and finally result in lowered antioxidant activity and Haugh unit of eggs yolk (Liu et al., 2014). Low egg shell thickness in birds supplemented with Diet D could be attributed to the antinutritional factors present in Moringa pods that disturb the calcium metabolism (Olugbemi et al. 2010; Paguia et al., 2014). Similar results were reported by Tesfaye et al. (2014), who showed that egg quality parameters such as Haugh unit and shell thickness did not change with increasing levels of Moringa in the diet, whereas feed efficiency increased. As reported by Gakuya et al. (2014), egg quality parameters remained unchanged in the treatment groups throughout the supplementation period. Contrary to the current results, other experiments reported that plants containing bioactive compounds, such as essential oils, flavonoids, and carotenoids, affect Haugh unit and shell thickness positively (Nobakht \& Moghaddam, 2013; Abbas, 2013).

Dietary supplementation of MPM in commercial layers may enrich egg yolks with $\beta$-carotene and quercetin. The results of the present study revealed that the highest values (539.93 \& 121.47) of $\beta$-carotene and quercetin were recorded in Group D, supplemented with $1.5 \%$ of MPM, whereas the lowest values were 
recorded in the control group. A similar trend was observed in the $\beta$-carotene and quercetin content of feed samples. Moringa pods are enriched with carotenoids and flavonoids, which are strong natural antioxidants that can modify egg yolk $\beta$-carotene and quercetin levels (Gakuya et al., 2014; Liu et al., 2014). This type of response may be attributed to higher levels of $\beta$-carotene and quercetin, $2.7-3.10 \mathrm{mg}$ and $80-150 \mathrm{mg}$ per $100 \mathrm{~g}$ pods, respectively (Lako et al., 2007; Tesfaye et al., 2014). Similarly, other researchers stated that $\beta$ carotene is deposited in egg yolk when supplemented with coloured carrots at $70 \mathrm{~g} / \mathrm{bird} /$ day in the basal diet (Okonkwo, 2009; Hammershoj et al., 2010). Most of the $\beta$-carotene is enriched in egg yolk, whereas quercetin is enriched in egg albumin in chelation with amino acids. Similar results were reported in other studies in which nutritionists used canthacol, M. oleifera leaf meal, tomato peel, coloured carrots, and apple skin to enrich egg yolk with $\beta$-carotene and quercetin (Olson et al., 2008; Gakuya et al., 2014; Liu et al., 2014). Similarly, various studies showed the positive impact of $M$. oleifera on antioxidant compound deposition in chicken egg yolks (Mbikay, 2012).

Egg yolk selenium values in commercial layers showed a significant linear increase as the dose rate was increased $(P \leq 0.05)$. The group supplemented with maximum levels showed the highest values of selenium, whereas the control group showed the lowest values (Table 4). This higher level of enrichment is based on the form of selenium (seleno-methionine, seleno-cystine), because organic selenium has better bioavailability and retention in tissues (Delezie et al., 2014). Moringa oleifera leaves and pods have $2.88 \mathrm{mg}$ and $25.7 \mathrm{mg} / 100 \mathrm{~g}$ Se per $100 \mathrm{~g}$ dried leaves, respectively (Table 1). Eggs can be enriched easily with selenium, a key trace mineral that is involved in multiple metabolic, antioxidant, immune stimulator, and antiageing processes. Because $M$. oleifera is enriched with organic selenium, its supplementation may affect egg selenium content (Delezie et al., 2014).

In a study conducted by Farrell (2013), it was concluded that supplementation of layer diets with organic selenium @ $0.4 \mathrm{mg} / \mathrm{kg}$ of feed, the deposition in eggs would reach up to $20-60 \mu \mathrm{g} / 100 \mathrm{~g}$ edible egg. Selenium and methionine have a close relationship in metabolism. Birds supplemented only with methionine $(3.2,4.0$, and $5.4 \mathrm{~g} / \mathrm{kg}$ ) without selenium showed $0.48,0.63$, and $0.62 \mu \mathrm{g} / \mathrm{g}$ of deposited selenium in egg yolk, whereas this deposition was increased with an increment of selenium (Wang et al., 2010; Gravena et al., 2011). An organic form of selenium can easily enrich eggs, as was shown in a study conducted by Bennett and Cheng, (2010), in which they used sodium selenite $(0.3 \mu \mathrm{g} \mathrm{Se} / \mathrm{g}$ of feed) along with selenium yeast SSAF-600 ${ }^{\oplus}$ (Diamond V Mills, Cedar Rapids, IA, USA), an organic source with the concentrations 1.0, 2.4, and $5.1 \mu \mathrm{g} \mathrm{Se} / \mathrm{g}$ of diet. They reported that by supplementing 0.3-0.5 $\mu \mathrm{g} / \mathrm{g}$ feed the eggs were enriched up to $10-29 \mu \mathrm{g}$ Se. From these studies, it can be concluded that the higher the bioavailability and concentration of the selenium source in the supplemented diet, the higher the assimilation rate in the egg yolk. Similarly, other studies reported that selenium yeast, seleno-methionine and sodium selenite enrich the egg yolk (Wang et al., 2010; Delezie et al., 2014).

Dietary supplementation of MPM manipulated the lipid profile of egg yolk, resulting in significant $(P$ $\leq 0.05$ ) decrease in total cholesterol (Table 4). The control diet showed the highest level of cholesterol. The lowest levels were recorded in the Group D supplemented with the maximum dose (Table 4). Plants are enriched with phytosterols, which decrease the cholesterol levels of eggs, and serum (Hussain et al., 2014). MPM is enriched with a sterol ( $\beta$-sitosterol), which is responsible for decreasing cholesterol content (Hussain et al., 2014). Cholesterol levels of eggs are also influenced by antioxidants (flavonoids and carotenoid) in the diet. Antioxidants potentiate the production of bile salts, which results in emulsification of fats and decrease in the absorption of lipids so decreasing the levels of cholesterol (Srinivasan, 2005; Nobakht \& Moghaddam, 2013). Plant sterols and antioxidants decrease the absorption process and expedite the faecal drain of cholesterol, resulting in a hypocholesterolemic effect (Benakmoum et al., 2013). Reduction in egg cholesterol level could be due to fibre contents of $M$. oleifera and cassava peel, which play a significant role in binding and excreting cholesterol (Ghasi et al., 2000; Oladun-joye et al., 2010; Olugbemi et al., 2010). 
Table 4 Mean $( \pm S E$ ) bioactive compounds and selenium in egg yolk and diet samples of commercial layers fed with different levels of Moringa oleifera pod meal

\begin{tabular}{lcccc}
\hline Parameter & A & B & C & D \\
\hline Diet sample & & & & \\
B-Carotene & & & & \\
Quercetin & $0.31^{\mathrm{d}} \pm 0.01$ & $0.58^{\mathrm{c}} \pm 0.01$ & $0.74^{\mathrm{b}} \pm 0.02$ & $0.83^{\mathrm{a}} \pm 0.02$ \\
Selenium & $0.48^{\mathrm{d}} \pm 0.02$ & $7.98^{\mathrm{c}} \pm 0.02$ & $15.58^{\mathrm{b}} \pm 0.11$ & $22.85^{\mathrm{a}} \pm 0.14$ \\
Yolk sample & $0.13^{\mathrm{d}} \pm 0.00$ & $0.31^{\mathrm{c}} \pm 0.00$ & $0.48^{\mathrm{b}} \pm 0.00$ & $0.69^{\mathrm{a}} \pm 0.01$ \\
B-Carotene & & & & \\
Quercetin & $293.23^{\mathrm{c}} \pm 6.80$ & $554.80^{\mathrm{b}} \pm 7.29$ & $627.87^{\mathrm{a}} \pm 16.44$ & $539.93^{\mathrm{b}} \pm 10.60$ \\
Selenium & $1.94^{\mathrm{d}} \pm 0.13$ & $39.32^{\mathrm{c}} \pm 0.08$ & $76.79^{\mathrm{b}} \pm 0.53$ & $121.47^{\mathrm{a}} \pm 2.12$ \\
Cholesterol & $13.98^{\mathrm{d}} \pm 0.23$ & $32.32^{\mathrm{c}} \pm 0.23$ & $50.77^{\mathrm{b}} \pm 0.23$ & $72.21^{\mathrm{a}} \pm 0.94$ \\
& $219.07^{\mathrm{a}} \pm 0.73$ & $216.88^{\mathrm{b}} \pm 0.7$ & $212.49^{\mathrm{c}} \pm 0.70$ & $201.87^{\mathrm{d}} \pm 0.67$
\end{tabular}

Superscripts on different means within row show significant difference $(P \leq 0.05)$; $\beta$-carotene, quercetin and selenium in diet sample: $\mathrm{mg} / \mathrm{kg} ; \beta$-Carotene, quercetin and selenium in yolk sample: $\mu \mathrm{g} / 100 \mathrm{~g}$, cholesterol: $\mathrm{mg} / 100 \mathrm{~g}$, DPPH: (1, 1 diphenyl -2-picrylhydrazyl) \%, A, B, C, and D: MPM dose levels of $0,5,10$, and $15 \mathrm{~g}$ respectively

The nutrient profile of egg yolk was significantly affected $(P \leq 0.05)$ by the supplementation of MPM in commercial layers. Moisture, crude protein, ash and ether extract were recorded during the trial (Table 5). The highest moisture and ether extract levels were recorded in the control group, and were lowest in MPM $1.5 \%$ group D. Maximum values of crude protein and ash were recorded in Group D whereas minimum values were reported in the control group (Table 5). The nutrient profiles of egg yolk and albumen may be altered with manipulation of the feed (Naber, 1979; Nimalarante \& Wu, 2015). Antioxidants, flavonoids, carotenoids, amino acids, additional protein and energy levels that result in lowered moisture may be the reason for the improved nutrient density of egg yolk (Nkukwana et al., 2014a; Nimalarante \& Wu, 2015).

Table 5 Mean $( \pm$ SE) nutrients $(\mathrm{g} / 100 \mathrm{~g})$ and mineral profile $(\mathrm{mg} / 100 \mathrm{~g})$ of egg yolk in commercial layers fed on different levels of Moringa oleifera pod meal

\begin{tabular}{lllll}
\hline Parameter & \multicolumn{1}{c}{ A } & \multicolumn{1}{c}{ B } & C & D \\
\hline Proximate & & & & \\
Moisture & & & & \\
Crude protein & $48.56^{\mathrm{a}} \pm 0.10$ & $47.75^{\mathrm{b}} \pm 0.10$ & $46.49^{\mathrm{c}} \pm 0.06$ & $46.20^{\mathrm{d}} \pm 0.11$ \\
Ash & $17.55^{\mathrm{c}} \pm 0.09$ & $18.42^{\mathrm{b}} \pm 0.09$ & $18.98^{\mathrm{a}} \pm 0.09$ & $19.00^{\mathrm{a}} \pm 0.09$ \\
Ether extract & $1.41^{\mathrm{b}} \pm 0.01$ & $1.45^{\mathrm{ab}} \pm 0.02$ & $1.46^{\mathrm{a}} \pm 0.01$ & $1.46^{\mathrm{a}} \pm 0.01$ \\
Mineral profile & $32.01^{\mathrm{a}} \pm 0.15$ & $31.05^{\mathrm{b}} \pm 0.14$ & $30.11^{\mathrm{c}} \pm 0.14$ & $30.11^{\mathrm{c}} \pm 0.14$ \\
Sodium & & & & \\
Potassium & $62.62^{\mathrm{b}} \pm 0.60$ & $64.50^{\mathrm{a}} \pm 0.61$ & $62.57^{\mathrm{b}} \pm 0.60$ & $62.7^{\mathrm{b}} \pm 0.60$ \\
Calcium & $108.95^{\mathrm{c}} \pm 0.35$ & $112.22^{\mathrm{b}} \pm 0.36$ & $115.59^{\mathrm{a}} \pm 0.37$ & $115.59^{\mathrm{a}} \pm 0.37$ \\
Magnesium & $132.27^{\mathrm{c}} \pm 0.30$ & $136.24^{\mathrm{b}} \pm 0.31$ & $138.97^{\mathrm{a}} \pm 0.32$ & $138.97^{\mathrm{a}} \pm 0.32$ \\
Phosphorus & $12.36^{\mathrm{c}} \pm 0.04$ & $12.77^{\mathrm{b}} \pm 0.05$ & $13.10^{\mathrm{a}} \pm 0.03$ & $13.03^{\mathrm{a}} \pm 0.03$ \\
& $388.11^{\mathrm{b}} \pm 4.09$ & $399.76^{\mathrm{ab}} \pm 4.21$ & $403.75^{\mathrm{a}} \pm 4.25$ & $403.75^{\mathrm{a}} \pm 4.25$
\end{tabular}

Superscripts on different means within row show significant difference $(P \leq 0.05)$

${ }^{1}$ Parameters for proximate analysis were expressed in $\mathrm{g} / 100 \mathrm{~g}$

${ }^{2}$ Parameters for mineral profile were expressed in $\mathrm{mg} / 100 \mathrm{~g}$

$A, B, C$, and D: MPM dose levels of $0,5,10$, and $15 \mathrm{~g}$ respectively

Treatment groups recorded mineral profiles that were significantly different $(P \leq 0.05)$ from the control during the experimental period. The lowest values of sodium, potassium, calcium, magnesium, and phosphorus were observed in the group offered the basal diet, and highest in the groups supplemented with 
MPM (Table 5). Moreover, all these values remained significantly the same in the 1.0 and $1.5 \%$ supplementation groups. The mineral profile of egg yolk samples was significantly improved $(P \leq 0.05)$ and can be attributed to the higher ash content of MPM, which eventually results in higher levels of all minerals in the egg yolk (Surai \& Sparks, 2001). Similar findings were reported in previous studies (Nkukwana et al., 2016; Qwele et al., 2013). Similar results were reported in the estimation of calcium in tibia bone and ash content with M. oleifera supplementation (Nkukwana et al., 2014b; Gravena et al., 2011).

Feed supplemented with MPM significantly affected serum biochemistry $(P \leq 0.05)$. Serum SGPT, glucose, creatinine and cholesterol levels were highest in the control group and lowest in the group supplemented 1.0\% MPM (Table 6). However, all other biomarkers, expressed a quadratic trend as the supplementation level was increased. Antibody titers against Newcastle disease remained the same during the whole experimental period. MPM did not affect the immune status of the birds (Table 6). Bioactive compound flavonoids (quercetin) and carotenoids ( $\beta$-Carotene) positively affected and reduced the levels of SGPT, creatinine, glucose and cholesterol levels in the serum, which showed improved liver performance, whereas lowered creatinine levels indicated better kidney functionality in MLM-supplemented groups (Melesse et al., 2013; Elkloub et al., 2015). Lowered cholesterol levels in the serum show the hypocholesterolemic effect of MLM, which might be attributed to $\beta$-sitosterol-rich plant material, which has same structure as cholesterol and lowers uptake from the intestine (Ghasi et al., 2000). These antioxidants ( $\beta$-Carotene and quercetin) and phytosterols ( $\beta$-Sitosterol) affect the functionality of liver, kidneys and heart, resulting in improved metabolism, as indicated in biochemical parameters and antibody titers (Ghasi et al., 2000). Essential oils in plants affect antibody titers positively (Ozek et al., 2011; Goudarzi et al., 2016). Contrary to the current study, Bardzardi et al. (2014) reported that no change in the immune response of birds when their diet was supplemented with bioactive compounds of plant origin.

Table 6 Mean ( \pm SE) serum glutamic-pyruvic transaminase $(\mathrm{U} / \mathrm{L})$, glucose $(\mathrm{mg} / \mathrm{dL})$, creatinine $(\mathrm{mg} / \mathrm{dl})$, and cholesterol $(\mathrm{mg} / \mathrm{dl})$ and antibody titers of commercial layers fed on Moringa oleifera pod meal

\begin{tabular}{lcccc}
\hline Parameter & A & B & C & D \\
\hline Blood metabolites and antibody response of serum & sample (4 weeks) & & \\
SGPT & $25.46^{\mathrm{a}} \pm 0.37$ & $19.56^{\mathrm{b}} \pm 0.67$ & $14.05^{\mathrm{d}} \pm 0.35$ & $15.97^{\mathrm{c}} \pm 0.42$ \\
Glucose & $271.27^{\mathrm{a}} \pm 1.56$ & $253.13^{\mathrm{b}} \pm 0.93$ & $241.67^{\mathrm{c}} \pm 0.73$ & $250.87^{\mathrm{b}} \pm 1.25$ \\
Creatinine & $1.66^{\mathrm{a}} \pm 0.01$ & $1.28^{\mathrm{b}} \pm 0.03$ & $1.10^{\mathrm{d}} \pm 0.01$ & $1.20^{\mathrm{c}} \pm 0.01$ \\
Cholesterol & $163.07^{\mathrm{a}} \pm 1.36$ & $140.60^{\mathrm{b}} \pm 1.17$ & $87.00^{\mathrm{c}} \pm 1.41$ & $83.47^{\mathrm{c}} \pm 1.13$ \\
Blood metabolites and antibody response of serum & sample (6 weeks) & & \\
SGPT & $25.21^{\mathrm{a}} \pm 0.37$ & $19.37^{\mathrm{b}} \pm 0.67$ & $13.91^{\mathrm{d}} \pm 0.35$ & $15.81^{\mathrm{c}} \pm 0.42$ \\
Glucose & $268.55^{\mathrm{a}} \pm 1.54$ & $250.60^{\mathrm{b}} \pm 0.92$ & $239.25^{\mathrm{c}} \pm 0.73$ & $248.36^{\mathrm{b}} \pm 1.23$ \\
Creatinine & $1.64^{\mathrm{a}} \pm 0.01$ & $1.26^{\mathrm{b}} \pm 0.03$ & $1.09^{\mathrm{d}} \pm 0.01$ & $1.19^{\mathrm{c}} \pm 0.01$ \\
Cholesterol & $161.44^{\mathrm{a}} \pm 1.34$ & $139.19^{\mathrm{b}} \pm 1.15$ & $86.13^{\mathrm{c}} \pm 1.39$ & $82.63^{\mathrm{c}} \pm 1.12$ \\
NDV titers & $44.80 \pm 4.19$ & $51.20 \pm 4.19$ & $51.20 \pm 4.19$ & $51.20 \pm 4.19$ \\
& & & & \\
\hline
\end{tabular}

Superscripts on different means within row show significant difference $(P \leq 0.05)$; SGPT (serum glutamic-pyruvic transaminase): U/L; glucose, creatinine and cholesterol: $\mathrm{mg} / \mathrm{dL} ; \mathrm{A}, \mathrm{B}, \mathrm{C}$, and D: MPM dose levels of 0,5 , 10, and $15 \mathrm{~g}$ respectively; NDV: Newcastle Disease Virus

\section{Conclusion}

The results of the present study reveal that MPM could affect egg production and immunity positively, and might alter the bioactive compound index of egg yolk with variable results at different dose levels. The best results were recorded in the group supplemented with 1.5\% MPM in the basal diet. Additionally, it was shown that $M$. oleifera pods could be used as alternative growth promoters, which improves antioxidant content, and the performance of layer birds.

\section{Acknowledgements}

The authors thankfully acknowledge the administration of Ali Poultry Farm Chunian and Dr Naveed-ul-Haq, Department of Animal Nutrition, University of Veterinary and Animal Sciences, Lahore, for facilitating and funding the present experiment. 


\section{Authors' Contributions}

SA conducted this study as a part of his PhD research work under the supervision of AK, TNP and SM. KH and MSS helped in reviewing the manuscript. SA helped in statistical analysis and formatting of manuscript. MN and MS helped in collection of Moringa pods and execution of experiment.

\section{Conflict of Interest Declaration}

There is no conflict of interest among the authors in this research.

\section{References}

Abbas, T.E., 2013. The use of Moringa oleifera in poultry diets. Turk. J. Vet. Anim. Sci. 37, 492-496.

Abou-Elezz, F.M.K., Sarmiento-Franco, L., Santos-Ricalde, R. \& Solorio-Sanchez F., 2011. Nutritional effects of dietary inclusion of Leucaena leucocephala and Moringa oleifera leaf meal on Rhode Island Red hens' performance. Cuban. J. Agri. Sci. 45, 163-169.

Agbede, J.O., 2003. Equi-protein replacement of fish meal with Leucaena leaf protein concentrate; an assessment of performance characteristics and muscle development in chicken. Int. J. Poult. Sci. 2, 421-429.

Amaglo, N.K., Bennett, R.N., Curto, R.B., Rosa, E.A., Turco, V.L., Giuffrida, A., Curto, A.L., Crea, F. \& Timpo, G.M., 2010. Profiling selected phytochemicals and nutrients in different tissues of the multipurpose tree Moringa oleifera L, grown in Ghana. Food. Chem. 15, 1047-1054.

Anwar, F. \& Bhanger. M.I., 2003. Analytical characterization of Moringa oleifera seed oil grown in temperate regions of Pakistan. J. Agri. Food. Chem. 51, 6558-6563.

Ao. X., Yoo, J.S., Zhou, T.X., Wang, J.P., Meng, Q.W., Yan, L., Cho, J.H. \& Kim, I.H., 2011. Effects of fermented garlic powder supplementation on growth performance, blood profiles and breast meat quality in broilers. Livest.. Sci. $141,85-89$.

AOAC (Association of Official Analytical Chemists). Official methods of analysis. Arlington, Virginia, USA.

Ayasan, T., 2015. Use of Moringa oleifera in poultry and ruminant nutrition. Turkish. J. Agri. - Food. Sci. Technol. 3(6), 425-429.

Aye, P. \& Adegun M., 2013. Chemical Composition and some functional properties of Moringa, Leucaena and Gliricidia leaf meals. Agri. and Biolog. J. North. Am. 4, 71-77.

Banjo, O.S., 2012. Growth and performance as affected by inclusion of Moringa oleifera leaf meal in broiler chicks diet. J. Biol. Agri. Healthcare. 2, 2224-3208.

Bardzardi, M.M., Ghazanfari, S., Salehi, A. \& Sharifi, S.D., 2014. Growth performance, carcass characteristics, antibody titer and blood parameters in broiler chickens fed dietary myrtle (Myrtus communis) essential oil as an alternative to antibiotic growth promoter. Poult. Sci. J. 2(1), 37-49.

Benakmoum, A., Larid, R. \& Zidani, S., 2013. Enriching egg yolk with carotenoids \& phenols. Int. J. Biolog. Biomole. Agri. Food and Biotechnol. Eng. 7, 489-493.

Delezie, E., Rovers, M., Van der Aa, A., Ruttens, A., Wittocx, S., Segers, L., 2014. Comparing responses to different selenium sources and dosages in laying hens. Poult. Sci. 92, 3083-3090.

Duncan, D.B., 1955. Multiple range and multiple F test. Biometrics. 11, 1-42.

Elkloub, K., Moustafa, M.E.L., Riry, F.H., Mousa, M.A.M. \& Hanan, A.H., 2015. Effect of using Moringa oleifera leaf meal on performance of Japanese quail. Egypt. Poult. Sci. J. 35, 1095-1108.

El-Sheikh, N.I., El-Shazly, E.S., Abbas, E.A., Ghada, I.A. \& El-Gobary., 2015. Effect of Moringa leaves on lipid content of table eggs in layer hens. Egypt. J. Chem. Enviro. Health. 1, 291-302.

Embuscado, M.E., 2015. Spices and herbs: Natural sources of antioxidants - a mini review. J. Func. Foods. PP, 1-9.

Fadiyimu, A.A., Fajemisin, A.N., Alokan, J.A. \& Aladesanwa, R.D., 2010. Digestibility, nitrogen balance and haematological profile of West African dwarf sheep fed dietary levels of Moringa oleifera as supplement to Panicum maximum. J. Am. Sci. 6, 634-643.

Farida, A., Barkat, A.K., Nadia, N., Tariq, M. \& Sulaiman, F., 2008. Effect of boiling and storage on beta-carotene content of different vegetables. Pak. J. life. Soc. Sci. 6, 63-67.

Gakuya, D.W., Mbugua, P.N., Mwaniki, S.M., Kiama, S.G., Muchemi, G.M. \& Njuguna, A., 2014. Effect of supplementation of Moringa oleifera (lam) leaf meal in layer chicken feed. Int. J. Poult. Sci. 13, 379-384.

Ghasi, S., Nwobodo, E. \& Ofili, J.O., 2000. Hypo-cholesterolemic effects of crude extract of leaf of Moringa oleifera Lam in high-fat diet fed Wistar rats. J. Ethno. pharmacol. 69, 21-25.

Gopalakrishnanb, L., Doriyaa, K. \& Kumara, D.S., 2016. Moringa oleifera: A Review on nutritive importance and its medicinal application. Food. Sci. Human. Nutri. 5, 49-56.

Grashorn, M.A., 2010. Use of phytobiotics in broiler nutrition: an alternative to infeed antibiotics. J. Anim. Feed. Sci. 19, 338-347.

Gravena, R.A., Marques, R.H., Roccon, J., Picarelli, J., Hada, H.F., Silva, JDTD., Sandra Aidar de Queiroz, S.A.D. \& Moraes, V.M.B.D., 2011. Egg quality during storage and deposition of minerals in eggs from quails fed diets supplemented with organic selenium, zinc and manganese. R. Bras. Zootec. 40(12), 2767-2775.

Goudarzi, M., Samiei, I., Nanekarani, S. \& Nasrolahi, F., 2016. The effect of Myrtus communis oil extract on growth performance and immune responses in Ross and Cobb strain broilers. J. Adv. Agri. Technol. 3(1), 10-14.

Hammershoj, M., Kidmose, U. \& Steenfeldt, S., 2010. Deposition of carotenoids in egg yolk by short-term supplement of coloured carrot (Daucus carota) varieties as forage material for egg-laying hens. J. Sci. Food. Agric. 90(7), 11631171.

Hussain, S., Malik, F. \& Mahmood, S., 2014. An exposition of medicinal preponderance of Moringa oleifera (Lank.). Pak. J. Pharma. Sci. 27, 397-403. 
Kaijage, J.T., Mutayoba, S.K. \& Katule, A., 2015. Moringa oleifera leaf meal and molasses as additives in grain sorghum based diets for layer chickens. Livest. Res. Rural Develop. 27(2), 1-5.

Kırkpınar, F., Bora Ünlü, H. \& Özdemir, G., 2011. Effects of Oregano and Garlic essential oils on performance, carcase, organ and blood characteristics and intestinal microflora of broilers. Livest. Sci. 137, 219-225.

Lako, J., Trenerry, V.C., Wahlqvist, M., Wattanapenpaiboon, N., Sotheeswaran, S. \& Premier, R., 2007. Phytochemical flavonols, carotenoids and the antioxidant properties of a wide selection of Fijian fruit, vegetables and other readily available foods. Food. Chem. 101, 1727-1741.

Liu, H.N., Liu, Y., Hu, L.L., Suo, Y.L., Zhang, L., Jin, F. \& Li, Y., 2014. Effects of dietary supplementation of quercetin on performance, egg quality, cecal microflora populations, and antioxidant status in laying hens. Poult. Sci. 93, 347353.

Makkar, H.P.S. \& Becker, K., 1996. Nutritive value and ant nutritive components of whole and ethanol extracted Moringa oleifera leaves. Anim. Feed. Sci. Tech. 63, 211-218.

Makkar, H.P.S. \& Becker, K., 1997. Nutrient and anti-quality factors on different morphological parts of the Moringa tree. J. Agri. Sci. 128, 3111-322.

Manzoor, M., Anwar, F., lqbal, T. \& Bhanger, M.I., 2007. Physico- chemical characterization of Moringa concanensis seeds and seed oil. J. Am. Oil. Chem. Soc. 84, 413- 419.

Mbikay, M., 2012. Therapeutic potential of Moringa oleifera leaves in chronic hyperglycemia and dyslipidemia: a review. Front. Pharmacol. 3(24), 1-12.

Mehta, K., Balaraman, R., Amin, A.H., Bafna, P.A. \& Gulati, O.D., 2003. Effect of fruits of Moringa oleifera on the lipid profile of normal and hypercholesterolaemic rabbits. J. Ethno. Pharmacol. 86, 191-195.

Mohammed, K.A.F., Sarmiento-Franco, L., Santos-Recalde, R. \& Solorio-Sanchez, J.F., 2012. The nutritional effect of Moringa oleifera fresh leaves on Rhode Island Red hen egg production and quality. Trop. Anim. Health. Prod. 44, 1035-1040.

Moreki, J.C. \& Gabanakgosi, K., 2014. Potential use of Moringa oleifera in poultry diets. Global. J. Anim. Sci. Res. 2(2), 109-115.

Mughal, M.H., Ali, G., Srivastava, P.S. \& Iqbal, M., 1999. Improvement of drumstick (Moringa pterygosperma Gaertn.) - A unique source of food and medicine through tissue culture. Hamdard. Med. 42, 37-42.

Melesse, A., Getye, Y., Berihun, K. \& Banerjee, S., 2013. Effect of feeding graded levels of Moringa stenopetala leaf meal on growth performance, carcass traits and some serum biochemical parameters of Koekoek chickens. Livest. Sci. 157(2), 498-505.

Naber, E.C., 1979. The effect of nutrition on composition of eggs. Poult. Sci. 58, 518-528.

Nimalaratne, C. \& Wu, J., 2015. Hen egg as an antioxidant food commodity: A. Review. Nutrients. 7, 8274-8293.

Nkukwana, T.T., Muchenje, V., Masika, P.J., Pieterse, E., Hoffman, L.C. \& Dzama, K., 2014b. The effect of Moringa oleifera leaf meal supplementation on tibia strength morphology and inorganic contents of broiler chicken. South. Afr. J. Anim. Sci. 44(3), 228-239.

Nkukwana, T.T., Muchenje, V., Masika, P.J., Pieterse, E., Hoffman, L.C. \& Dzama, K., 2016. Proximate composition and variation in colour, drip loss and $\mathrm{pH}$ of breast meat from broilers supplemented with Moringa oleifera leaf meal over time. Anim. Prod. Sci. 56, 1208-1216.

Nkukwana, T.T., Muchenje, V., Pieterse, E., Masika, P.J., Mabusela, T.P., Hoffman, L.C. \& Dzamab, K., 2014a. Effect of Moringa oleifera leaf meal on growth performance, apparent digestibility, digestive organ size and carcass yield in broiler chickens. Livest. Sci. 161, 139-146.

Nobakht, A. \& Moghaddam, M., 2013. The effects of different levels of costmary (tanacetum balsamita) medicinal plant on performance, egg traits and blood biochemical parameters of laying hens. Iran. J. Appl. Anim. Sci. 3(2), 307312.

Okonkwo, J.C., 2009. Effect of breed and storage duration on the Beta-carotene content of egg yolk. Pak j Nutri. 8(10), $1629-1630$

Ola-Fadunsin, S.D. \& Ademola, I.O., 2013. Direct effects of Moringa oleifera Lam (Moringaceae) acetone leaf extract on broiler chickens naturally infected with Eimeria species. Trop. Anim. Health. Prod. 45, 1423-1428.

Oladunjoye, I. O., Ojebiyi, O. \& Amao, O.A., 2010. Effect of feeding processed cassava (Manihot esculenta Crantz) peel meal based diet on the performance characteristics, egg quality and blood profile of laying chicken. Agric. Trop. Subtrop. 43,119-126.

Olson, J.B., Ward, N.E. \& Koutsos, E.A., 2008. Lycopene incorporation into egg yolk and effects on laying hen immune function. Poult. Sci. 87, 2573-2580.

Olugbemi, T.S., Mutayoba, S.K. \& Lekule, F.P., 2010. Effect of Moringa (Moringa oleifera) inclusion in cassava based diets fed to broiler chickens. Int. J. Poult. Sci. 9, 363-367.

Ozek, K., Wellmann, K.T., Ertekin, B. \& Tarım, B., 2011. Effects of dietary herbal essential oil mixture and organic acid preparation on laying traits, gastrointestinal tract characteristics, blood parameters and immune response of laying hens in a hot summer season. J. Anim. Feed. Sci. 20, 575-586.

Paguia, H.M., Paguia, R.Q., Balba, C. \& Flores, R.C., 2014. Utilization and evaluation of Moringa oleifera L. as poultry feeds. 4th International Conference on Agriculture and Animal Science. 8, 343-7.

Portugaliza, H.P. \& Fernandez, T.J., 2011. Growth performance of Cobb broilers given varying concentrations of Malunggay (Moringa oleifera lam.) aqueous leaf extract. J. Anim. Feed. Res. 2, 465-469.

Qwele, K., Hugo, A., Oyedemi, S.O., Moyo, B., Masika, P.J. \& Muchenje, V., 2013. Chemical composition, fatty acid content and antioxidant potential of meat from goats supplemented with Moringa (Moringa oleifera) leaves, sunflower cake and grass hay. Meat. Sci. 93, 455-462. 
Rajasekaran, A., Sivagnanam, G. \& Xavier, R., 2008. Nutraceuticals as therapeutic agents: A review. Res. J. Pharm. Tech. 1, 328-340.

Rezaei, M., Moghaddam, H.N., Reza, J.P. \& Kermanshahi, H., 2004. The effects of dietary protein and Lysine levels on broiler performance, carcass characteristics and N excretion. Int. J. Poult. Sci. 3, 148-152.

Saini, R.K., Shetty, N.P., Prakash, M. \& Giridhar, P., 2014a. Effect of dehydration methods on retention of carotenoids, tocopherols, ascorbic acid and antioxidant activity in Moringa oleifera leaves and preparation of a RTE product. J. Food. Sci. Technol. 51, 2176-2182.

Saini, R.K., Shetty, N.P. \& Giridhar, P., 2014b. Carotenoid content in vegetative and reproductive parts of commercially grown Moringa oleifera Lam. cultivars from India by LC-APCI-MS. European. Food. Res. Tech. 238, 971-978.

Srinivasan, K., 2005. Spices as influencers of body metabolism: an overview of three decades of research. Food. Res. Int. 38, 77-86.

Steel, R.G.D., Torrie, J.H. \& Dickey, D.A., 1997. Principles and procedures of statistics. A biometrical approach. 3rd ed., McGraw Hill Book Co., New York, USA.

Surai, P.F. \& Sparks, N.H.C., 2001. Designer eggs: From improvement of egg composition to functional food. Trends. Food. Sci. Technol. 12, 7-16.

Tesfaye, E.B., Animut, G.M., Urge, M.L. \& Dessie, T.A., 2014. Cassava root chips and Moringa oleifera leaf meal as alternative feed ingredients in the layer ration. J. Appl. Poult. Res. 23, 614-624.

Tokusoglu, O., Unal, M.K. \& Yıldırım, Z., 2003. HPLC-UV and GC-MS characterization of the flavonol aglycons quercetin, kaempferol, and myricetin in tomato pastes and other tomato-based products. Acta. Chromatogr. 3, 196-207.

Wallace, R.J., Oleszek, W., Franz, C., Hahn, I., Baser, K.H.C., Mathe, A. \& Teichmann, K., 2010. Dietary plant bioactive for poultry health and productivity. Brit. Poult. Sci. 51, 461-487.

Wang, Z.G., Pan, X.J., Zhang, W.Q., Peng, Z.Q., Zhao, R.Q. \& Zhou, G.H., 2010. Methionine and selenium yeast supplementation of the maternal diets affects antioxidant activity of breeding eggs. Poult. Sci. 89, 931-937.

Windisch, W., Schedle, K., Plitzner, C. \& Kroismayr, A., 2008. Use of phytogenic products as feed additives for swine and poultry. J. Anim. Sci. 86, 140-148.

Yang, R.Y., Chang, L.C., Hsu, J.C., Weng, B.B.C., Palada, M.C., Chadha, M.L. \& Levasseur V., 2006. Nutritional and functional properties of Moringa leaves, from germ plasm to plant to food to health. Moringa and other highly nutritious plant resources: Strategies, standards and markets for a better impact on nutrition in Africa. Accra Ghana. November 16-18.

Zanu, H.K., Asiedu, P., Tampouri, M., Abada, M. \& Asante, I., 2012. Possibilities of using Moringa (Moringa oleifera) leaf meal as a partial substitution for fish meal in broiler chicken diets. J. Anim. Feed. Res. 2, 70-75. 